\title{
Viola gelida, a new, rare and vulnerable rosulate species from the high Andes of Atacama Region, Chile
}

\section{Viola gelida, una nueva especie rosulada, rara y vulnerable del sector altoandino de la Región de Atacama, Chile}

\author{
John M. Watson ${ }^{1 *}$, María Paz Cárdenas ${ }^{2}$, Ana R. Flores ${ }^{1}$, Jorge Macaya $^{2}$, Héctor Jímenez $^{2} \&$ \\ JeSSICA BARRÍA ${ }^{2}$ \\ ${ }^{1}$ Casilla 161, Los Andes, Valparaíso. \\ ${ }^{2}$ Cedrem Consultores, Padre Mariano 82, Oficina 1003, Providencia, Santiago.

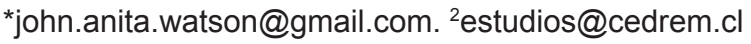

\begin{abstract}
RESUMEN
Se provee la descripción para Viola gelida, conocida sólo de dos sitios cercanos en el desierto seco y frío de gran altura. Se identifican las características que distinguen su estrecha relación con Viola exsul y otros parientes cercanos. Además, se discute el contexto de su descubrimiento en un estudio de impacto ambiental obligatorio.
\end{abstract}

The new taxon belongs in Viola L. sect. Andinium W. Becker (Violaceae). This large infrageneric group comprises ca. 96 species. An informed estimate gives the species count for the genus Viola itself as approximately 600 (T. Marcussen pers. comm.). Sect Andinium has an almost uninterrupted longitudinal distribution between the equator and $47^{\circ} \mathrm{S}$, and occurs at elevations from the Pacific coast to the upper Andean vegetational zone. Chile hosts 51 published species accepted here. The present novelty is included in these statistics.

Implementation in January 2011 of a formal, regulatory environmental impact survey, which had resulted from an application to commence mining operations, led to discovery of the new species in the cordilleras above Copiapó, close to the border with Argentina. No more than a single sample per taxon at any site was required or taken. This viola did not in any case immediately register as new to science. But its status and significance were fully appreciated when a later survey took place during October 2011. Consequently, following detection then of a second, more populous colony further south, it was possible to gather a prudent but adequate quantity of type material.

Viola gelida J.M. Watson, M.P. Cárdenas \& A.R. Flores, sp. nov. (Figs 1, 2).

TYPE: CHILE, Región de Atacama, Prov. Copiapó, en las cercanías del Río La Gallina, $27^{\circ}$ 47' 38.586”S 69 7' 29.539”W, 4843 m, 24.10.2011, leg. M.P. Cárdenas, Vsp.01 (Holotype: CONC; isotypes: SGO, ULS, Herb. CEDREM, Herb. Watson \& Flores).
Related to Viola exsul J.M. Watson \& A.R. Flores, and less closely to V. frigida Phil. It may be distinguished from the first principally by their divergent indumentum types and distributions or absence on leaf, peduncle and calyx surfaces; also by the dissimilar insertion of their stipules and bracteoles. Differences from V. frigida include perennial as opposed to annual life-form; absence of foliar glands; plane-crenate, not sinuate margins; and navicular, not plane lowermost petal.

Perennial, dwarf, rosulate hemicryptophyte; (as seen) rarely forming more than solitary imbricate-compressed rosettes, 3-4.5 cm in diameter. Rootstock axial, subfusiform, 5-6 cm long, ca $2 \mathrm{~mm}$ thick above, often furnished at points throughout with feeder roots. Caudex $5 \mathrm{~mm}$ long, covered by sclerified leaf scars. Rosette multifoliar, centrally depressed, mature outer and lower foliage less tightly imbricated. Leaves spathulate, stipulate, $1.5-2 \mathrm{~cm}$ long; blade 5-6 × 4-4.5 mm, obovate-cuneate, obtuse; upper surface reticulate-alveolate, densely and evenly invested in minute white papillose indumentum; undersurface glabrous to subglabrous; margin tri-crenulate per side, retrorsely ciliate with short, stout, white-hyaline bristles, sparse towards blade apex; pseudopetiole 1-1.4 cm long, broad, thick-succulent, glabrous, pinkish red; stipules inserted shortly above petiole base, 1.7-2 mm long, linear, acute, hyaline. Flowers solitary, axial, white, upper petals dark. Peduncle equalling or slightly exceeding upper submature leaves, pinkish red basally, glabrous except white-papillose upper surface of apical curve; bracteoles inserted shortly 
above base, attached above to peduncle by membrane, 2-2.5 mm long, linear-oblanceolate, obtuse, hyaline. Calyx subglabrous, $2.5-3.5 \mathrm{~mm}$ long; sepals pouched basally; upper sepal deltoid; lateral sepals asymmetrically lanceolate; lower sepals asymmetrically lanceolate with basal projection below. Corolla glabrous; upper petals 4-4.5 × 2-2.3 mm, narrowly obovate, obtuse, dark blue with fine green-yellow margin, face often irregularly white above; lateral petals 6-7 $\times 2.5-3 \mathrm{~mm}$, asymmetrically oblong, cuneate, with ca 3 longitudinal veins, tip rounded; lowermost petal 9-12 $\times$ 6-7 mm, limb naviculate, obcordate, lined with 9 subparallel longitudinal, dark black-violet veins, apex deeply retuse, terminal lobes rounded. Spur 1.2-1.5 mm long and broad, somewhat bifid. Style 1-1.2 mm long, geniculate, clavate; crest subrotund, entire. Fruit capsule glabrous, 3-valved; seeds unseen.

The epithet gelida refers to the frosty appearance of the upper leaf surface (Fig. 1b) as well as the cryogenic habitat. It also happens to provide a Latinised philological link with its sympatric relative from the same elevations, Viola frigida.
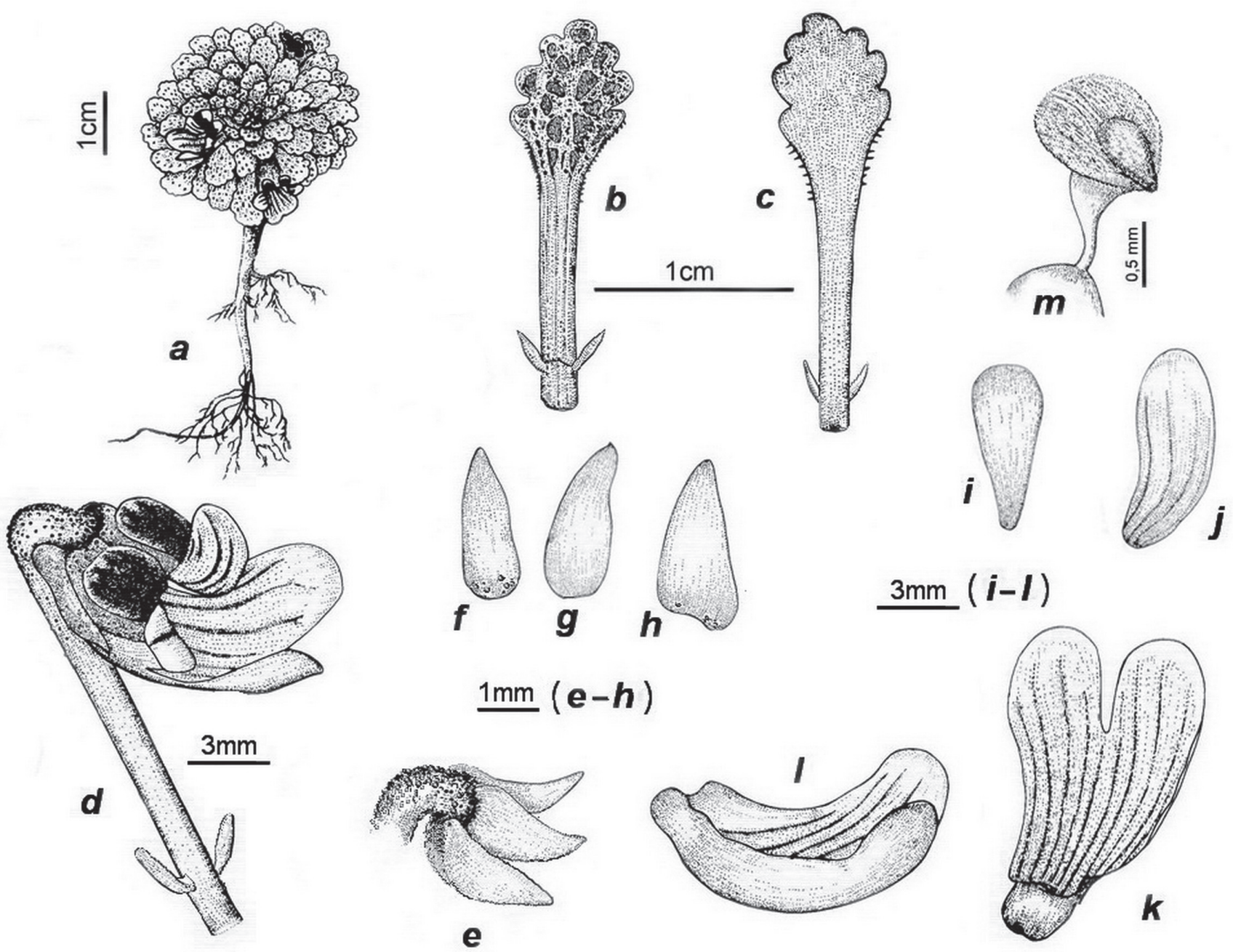

$3 \mathrm{~mm}(i-I)$

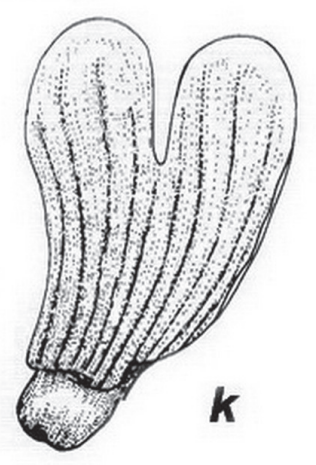

Figure 1.Viola gelida J.M. Watson, M.P. Cárdenas \& A.R. Flores. $a$. Plant, $b$. Leaf face, $c$. Leaf undersurface, $d$. Flower, $e$. Calyx, $f$. Upper sepal, $g$. Lateral sepal, $h$. Lower sepal, $i$. Upper petal, $j$. Lateral petal, $k$. Lowermost petal showing distinctive veining, $l$. Lowermost petal showing navicular form, $m$. Style and crest. (Del. Pedro Arias).

Figura 1. Viola gelida J.M. Watson, M.P. Cárdenas \& A.R. Flores. $a$. Planta, $b$. Haz de la hoja, $c$. Envés de la hoja, $d$. Flor, $e$. Cáliz, $f$. Sépalo superior, $g$. Sépalo lateral, $h$. Sépalo inferior, $i$. Pétalo superior, $j$. Pétalo lateral, $k$. Pétalo inferior mostrando la venación distintiva, $l$. Forma navicular del pétalo inferior, $m$. Estilo y cresta. (Del. Pedro Arias). 

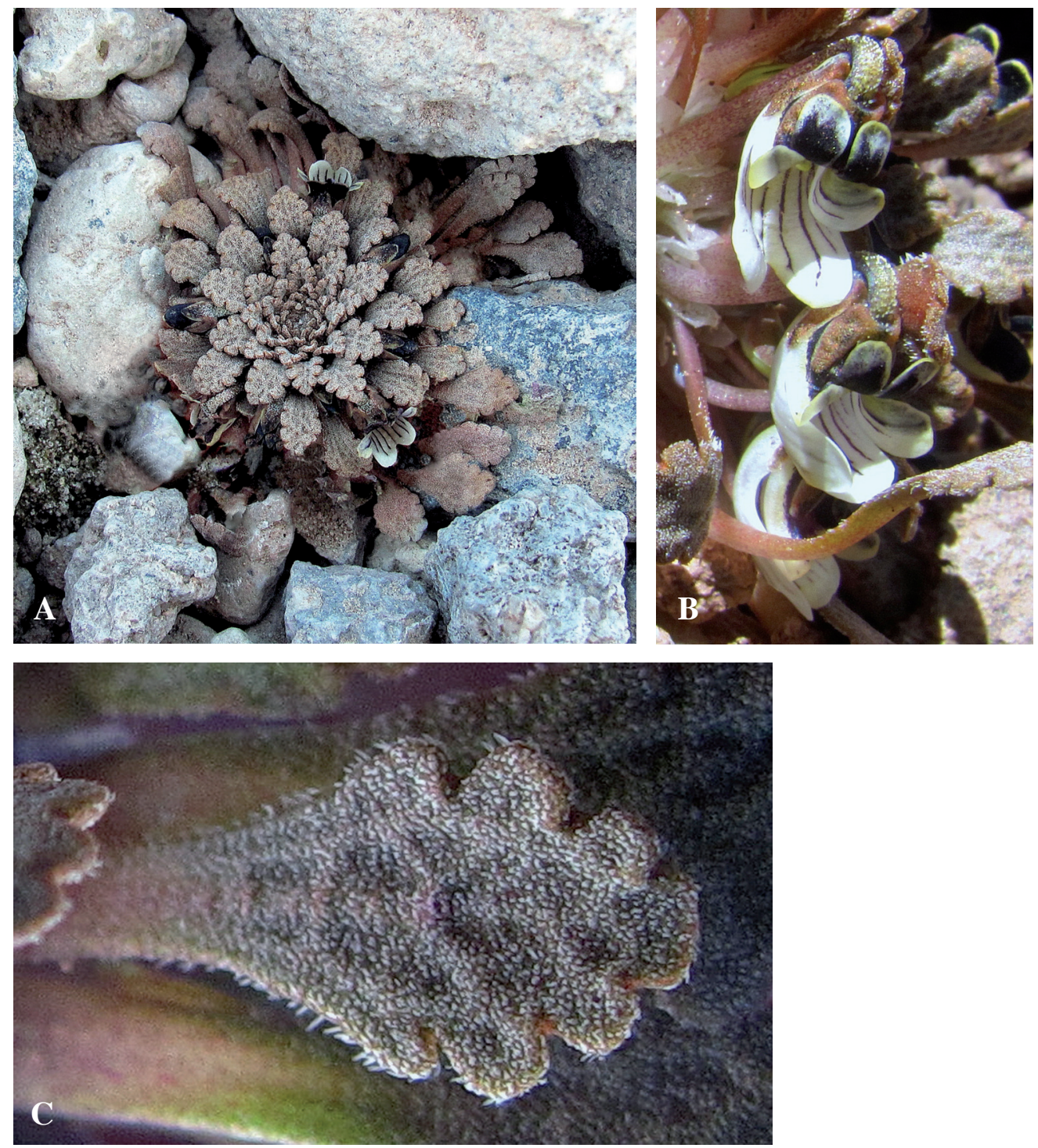

Figure 2. A: V. gelida in situ, Quebrada del Llano. B: Flower detail. C: Leaf face detail. (Photos: M.P. Cárdenas, 14 January and 24 October 2011).

Figura 2. A: $V$. gelida in situ, Quebrada del Llano. B: Detalle de la flor. C: Detalle de la cara de la hoja. (Fotos: M.P. Cárdenas, 14 enero y 24 octubre 2011).

ADDitional MATERIAL

CHILE, Región de Atacama, Prov. Copiapó, Quebrada

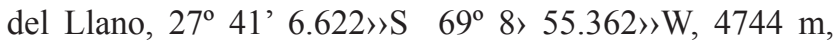
14.01.2011, leg. M.P. Cárdenas, MPC173(2)! (Herb. CEDREM).

TAXONOMIC AfFinities

$V$. gelida belongs within the major, widespread, polymorphic Viola volcanica Gillies ex Hook. \& Arn. alliance. At first sight its most immediate relative appeared to be annual $V$. frigida, commonest of a small complex of species possessing narrow leaves with crenate or sinuate-crenate borders. Despite clear foliar distinctions, as well as their contrasting life-spans, the corollas of both are notably alike, including their unique venation. However, one critical dissimilarity, the navicular lower petal of $V$. gelida, drew attention to its surprising and even closer relationship with recently described perennial $V$. exsul from nearby Argentina (Rossow et al. 2003). That species is situated at $4250 \mathrm{~m}$ in San Juan Province, close to the border with Chile and 300 $\mathrm{km}$ almost due south of $V$. gelida. Morphological differences and their significant allopatric distributions are sufficient to justify taxonomic separation of $V$. gelida from $V$. exsul. Should intermediates ever be discovered, a reassessment would be required. 
Viola exsul indumentum consists of hyaline bristles, at times with additional facultative pubescence. That species has basal stipules and bracteoles. It also displays a strong tendency to form a multiple crown of shortly-branched, intermeshed rosettes with an apparent looser disposition, all these features in contrast to $V$. gelida. In addition, the relative size and proportions of several of their character states, notably leaves and petals, are at variance.

Resemblance between $V$. frigida and the geographically remote annual Patagonian Viola tectiflora W. Becker was noted by Rossow (1988). V. frigida is not found further south than Aconcagua province, signifying a disjunction of $500 \mathrm{~km}$ between these two close Andean allies. The exact relationships of this group require resolving by molecular investigation.

\section{ENVIRONMENTAL CONSIDERATIONS}

In 2010 Cedrem Consultores was contracted by Compañía Minera Cerro Casale (CMC), a Barrick Gold Corporation subsidiary, to execute a survey (biological baseline for the EIS Optimización de Proyecto Minero Cerro Casale) in connection with mineral exploitation in the high Andes of central Atacama Region above Copiapó (Fig. 3).

Characterization of vegetation was based on Etienne \& Prado methodology (1982). Quantitative data accorded with the parameters of Braun-Blanquet (1979).
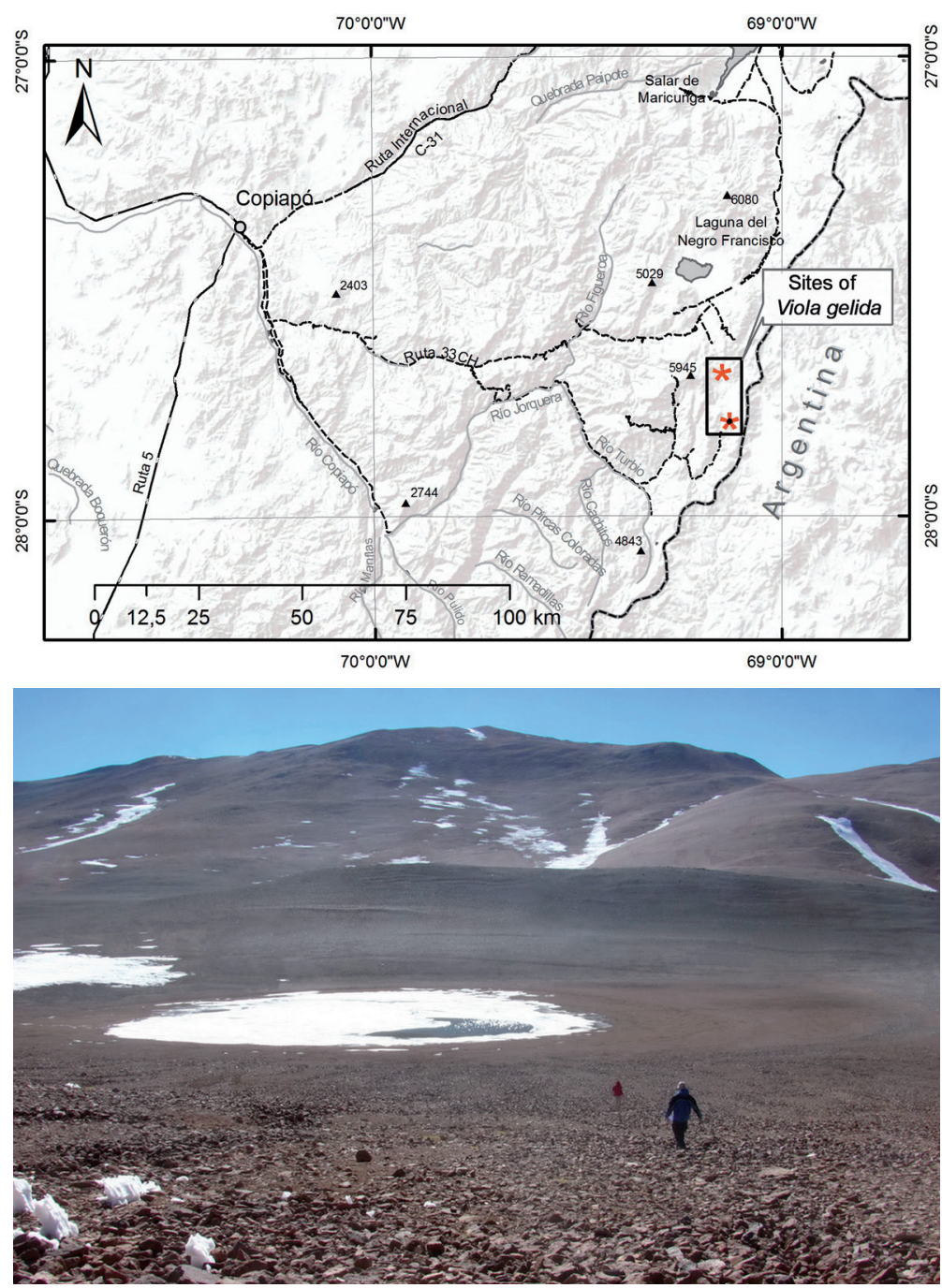

Figure 3. A: Map including most of the full survey area in central Atacama Region, Chile, with the two known locations of Viola gelida J.M. Watson, M.P. Cárdenas and A.R. Flores marked by red asterisks. The type site asterisk in the south has a black centre. B: Type locality and habitat with remnants of snow penitents or penitentes in foreground and seasonal ice-pond in mid-distance. (Photo: M.P. Cárdenas, 24 October 2011).

Figura 3. A: Mapa que incluye la mayor parte del área total de estudio en el centro de la Región de Atacama. Chile, con las dos localidades conocidas de Viola gelida J.M. Watson, M.P. Cárdenas and A.R. Flores marcadas con asteriscos rojos. El asterisco con el centro negro indica el sitio del tipo al sur. B: Localidad y hábitat con restos de los penitentes de nieve en primer plano y el charco de hielo temporal a media distancia. (Foto: M.P. Cárdenas, 24 octubre 2011). 
Gentle slopes and depressions at $4800 \mathrm{~m}$, subtended by low, rounded uppermost ridges, describes the La Gallina periglacial type habitat, with terrain largely surfaced by porphyric volcanic rock fragments of paleozoic/ carboniferous age, and at a distance apparently devoid of plant-life. The sparse vegetation is restricted to a few local patches on shallowly sloping easterly exposures which receive sufficient meltwater. This ablates from persistent winter snowdrifts, which often develop Andean snow penitents or penitentes, distinctive, tapered columnar structures angled towards the sun, remnants of which can be seen in the accompanying illustrations (Fig. 3).

Four dwarf chamaephytes constitute the community, which classifies as high Andean desert tundra. Senecio volckmannii Phil. is dominant, the remaining three being Menonvillea cuneata (Gillies \& Hook.) Rollins, Nototriche clandestina (Phil.) A.W. Hill and Viola gelida. These frequently grow down between rock débris to escape windstress and low air temperatures. Where vegetation exists, it was calculated at under $10 \%$, with $V$. gelida not exceeding $5 \%$. Its population at La Gallina may amount to a total in the order of several hundred individuals.

The original Viola gelida count at Quebrada del Llano was minimal, with no more than 10 specimens seen. This is by no means uncommon for sect. Andinium (Watson \& Flores 2007), exposing many of its taxa to high risk of extinction. Despite frequent tracks of guanacos, Lama guanicoe (Müller), at La Gallina, no destruction of plants was evident, contrasting with heavy damage to violas noted at Quebrada del Llano. This is suspected as having been caused by the medium-sized, omnivorous high Andean lizard, Liolaemus rosenmanni Núñez \& Navarro, whose presence was recorded there. As observed, viola rosettes had in fact recovered, due to protection of the depressed meristems by rocks.

The mine project has been approved. The concession requires the La Gallina area to be left untouched, with the prospect of becoming a natural reserve. That would be an invaluable protective measure for the only known appreciable population of $V$. gelida. The future of the diminutive other colony is less certain.

\section{ACKNOWLEDGEMENTS}

We express our gratitude to the Environmental Management of Compañía Minera Cerro Casale, staff of the field camps, and the experts of MWH Chile, who all collaborated valuably during the fieldwork. Oliver Clarke kindly assisted with digital manipulation of the $V$. gelida drawings. Our appreciation also for valuable improvements suggested by a reviewer.

\section{BIBLIOGRAPHY}

Braun-Blanquet, J. 1979. Fitosociología. Bases para el estudio de las comunidades vegetales. H. Blume Edic., Madrid, 820 pp.

Etienne, M. \& C. Prado. 1982. Descripción de la Vegetación mediante la Cartografía de Ocupación de Tierras. Ediciones Universidad de Chile. 120 pp.

Rossow, R.A. 1988. Viola tectiflora. En: M.N. Correa (ed.), Flora Patagónica 5: 186, 188. INTA, Buenos Aires.

Rossow, R.A., J.M. Watson \& A.R. Flores. 2003. Viola exsul. En: R. Kiesling (ed.), Flora de San Juan, República Argentina 2: 145-146. Estudio Sigma, Buenos Aires.

WAtson, J.M. \& A.R. Flores. 2007. Violas rosuladas en la flora de Chile. Chagual 5: 33-47.

Recibido: 09.07.13

Aceptado: 09.09.13 